\title{
Marie Carrière, Curtis Gillespie and Jason Purcell, Ten Canadian Writers in Context
}

Robert Kroetsch Series. Alberta: U of Alberta P, 2016. 202 p. ISBN (pb):

978-1-77212-141-4

\section{Charlotte Sturgess}

\section{(2) OpenEdition}

\section{Journals}

Electronic version

URL: http://journals.openedition.org/ces/305

DOI: $10.4000 /$ ces.305

ISSN: 2534-6695

Publisher

SEPC (Société d'études des pays du Commonwealth)

\section{Printed version}

Date of publication: 1 April 2018

Number of pages: 149-150

ISSN: 2270-0633

Electronic reference

Charlotte Sturgess, "Marie Carrière, Curtis Gillespie and Jason Purcell, Ten Canadian Writers in Context", Commonwealth Essays and Studies [Online], 40.2 | 2018, Online since 05 November 2019, connection on 06 April 2021. URL: http://journals.openedition.org/ces/305; DOI: https://doi.org/10.4000/ces.305

\section{(c) (i) $\Theta($}

Commonwealth Essays and Studies is licensed under a Licence Creative Commons Attribution - Pas d'Utilisation Commerciale - Pas de Modification 4.0 International. 


\section{Reviews}

Ten Canadian Writers in Context. Edited by Marie Carrière, Curtis Gillespie and Jason Purcell. Robert Kroetsch Series. Alberta: U of Alberta P, 2016. 202 p. ISBN (pb): 978-1-77212-141-4. CA\$24.95.

Reviewed by Charlotte STURGESS

Ten Canadian Writers in Context is an anthology that has emerged from a series of "Brown Bag Lunches," readings by authors at the Canadian Literature Centre of the University of Alberta over the last ten years. The title of the collection strangely reverberates through time and cultural change to that seminal work Eleven Canadian Novelists published in the 1970s which, albeit a set of interviews, was doubtless the first collection to bring to the wider reading public the idea that there existed a category of quality creative endeavour that could be classed loosely as Canadian writing. Since the 1970s Canadian writing has been widely acknowledged in all its cultural and racial diversity: through a plethora of novels, short stories, plays and poetry, and also through the many collections showcasing, for example, Italian-, Asian-, Indigenous- or Black-Canadian writing published in the last decades.

All this inevitably begs the question: why yet another anthology on Canadian writing? What does Ten Canadian Writers in Context offer that is lacking in the landscape of critical perceptions and appreciations already out there on the reading market?

It has to be said that, at first glance, this reader was fairly dubious as to the innovative value of an anniversary collection of readings that seemed to promise no particular cohesion in form or content. But, from the editor's introduction on, the critical and creative project of the volume began to take shape, confirmed and complexified by the form and content of the collection, by the choices made and the ideas behind them.

As the editors make clear in the introduction, the critical premise of the volume was to not "rely on nationalistic tropes" nor "contribute to the mythologies of a unified nation"(xi). Instead, their clearly stated objective was to represent the diversity of Canadian literary voices and Canadian languages - two of the excerpts are in French, one in Cree - as well as featuring the genres of poetry, fiction and non-fiction. Each of the ten excerpts is preceded by a bio-note by the author, a short critical essay deliberately eschewing close readings and privileging, on the editors' instructions, "a point of entry" into the author's work (xiii), thus encouraging a politics of outreach to communities of readers inside and outside the academy. Obviously, as for any anthology, choices had to be made since the centre has hosted over fifty authors since its inception. Choice - and thus its corollary, exclusion - is justified by the project of diversity and difference underpinning the volume: an overt critical focus on what distinguishes the individual writings rather than what unites them. The volume does indeed reflect this decentring impulsion while concomitantly tracing the fault lines of the Canadian imaginary in its richness of geographical breadth and cultural depths. The binding premise is that of privileging a writerly self-location rather than inserting the writings in any over-arching discourse of the nation. Thus, the volume encompasses "the caveats of familial ties (Ying Cheng); 
the affects of shame (Lynn Coady); the anxiety of cultural loss (Michael Crummy); the tricks of memory (Caterina Edwards); late-life despair, surprise and comedy (Marina Endicott); the dynamics of race and language (Lawrence Hill); the biting humour of poetic allegory (Alice Major); the ethics of storytelling (Eden Robinson); the sacredness of love (Gregory Scofield); and the perils and gains of exile (Kim Thúy)"(xi).

Ten Canadian Writers in Context is a volume that comes from, and further contributes to, a certain tradition of creative and critical praxis of transitivity that has, since the decentring lyrical materialism of Robert Kroetsch or the "geografictione" of Aritha van Herk, resolutely questioned, or actively dismantled, the border between the critical and the creative. The volume comes from conscious recognition that literature is a politics as well as a poetics, enmeshed in a specific cultural and ideological time and space. In this respect, the hegemonising tendency of any critical or creative enterprise is fully acknowledged by the editors who, themselves, come to writing and criticism from diverse professional perspectives: Marie Carrière, the director of the Canadian Literature Centre, teaches Canadian literature in both French and English - a fairly uncommon trans-lingual academic positioning reflected in her own critical writings; Curtis Gillespie is a writer and editor; Jason Purcell is a graduate student and Communications Officer for the Canadian centre. Openness, dialogue and a certain healthy scepticism towards the power of literary canon-making and meta-discourses are thus at the heart of the enterprise. What is more, the anthology is itself enmeshed in a larger, digital project entitled Inside the Bag: Can Lit Alive! which provides recordings of the readings as well as supplementary materials - part of the outreach strategy of the centre.

In fact, Ten Canadian Writers in Context is an exercise in reading otherwise. Anthologies, despite their obvious and legitimate aim to bring writers and writings to the notice of the general public by providing tasty snippets in order to whet the appetite, generate a certain frustration: that of an appetite not immediately satiated since a snippet remains a snippet. Yet, doubtless because this particular anthology is moulded into, and springs from a coherent project - a project that refutes coherence as a hegemony - it produces its own reading pleasure. The reader experiences the fluid transition from notes about the authors to comprehensive essays on their work and finally to the excerpts from their own work while journeying across styles, themes, geographical and cultural sites. A reading pleasure which in no way diminishes that of discovering writings one then cannot wait to read in full.

The only bone this reader would pick with Ten Canadian Writers in Context is the decision not to provide an English translation for the two Quebecois contributions, those of Ying Chen and Kim Thúy. Although fully understanding the (highly sensitive) politics of language that motivated the decision, one wonders if this kind of ideological bias is not counter-productive. Moreover, when the essay introducing the work is in English it seems rather nonsensical to prevent the non-bilingual reader (and there are many in the English-speaking world where French is not an official language, as well as in Canada itself) from appreciating those writers' works. Bridges generally promote dialogue and outreach more productively than garrisons.

That said, this is a very well thought out and carefully compiled volume, bringing exciting writings to a wide reading public. The editors are to be applauded for the difficult task accomplished and the extremely fruitful, innovative result obtained. 